\title{
Oxidant-mediated Epithelial Cell Injury in Idiopathic Pulmonary Fibrosis
}

\author{
Andre M. Cantin, Susan L. North, Gerald A. Fells, Richard C. Hubbard, and Ronald G. Crystal \\ Pulmonary Branch, National Heart, Lung, and Blood Institute, National Institutes of Health, Bethesda, Maryland 20892
}

\begin{abstract}
Lung inflammatory cells of patients with idiopathic pulmonary fibrosis (IPF) were evaluated for their ability to injure ${ }^{51} \mathrm{Cr}$ labeled AKD alveolar epithelial cells in the presence and absence of IPF alveolar epithelial lining fluid (ELF). The IPF cells were spontaneously releasing exaggerated amounts of superoxide $\left(\mathrm{O}_{2}^{\dot{亠}}\right)$ and hydrogen peroxide $\left(\mathrm{H}_{2} \mathrm{O}_{2}\right)$ compared with normal $(P$ $<0.02)$. Cytotoxicity of the AKD cells was markedly increased when the IPF inflammatory cells were incubated with autologous ELF $(P<0.02)$. The majority of IPF patients had ELF myeloperoxidase levels above normal $(P<0.002)$. Incubation of IPF ELF with AKD cells in the presence of $\mathrm{H}_{2} \mathrm{O}_{2}$ caused increased cellular injury $(P<0.01$ compared with control), which was suppressed by methionine, a myeloperoxidase system scavenger. IPF patients with high concentrations of ELF myeloperoxidase deteriorated more rapidly than those with low ELF myeloperoxidase $(P<0.05)$. Thus, IPF is characterized by an increased spontaneous production of oxidants by lung inflammatory cells, the presence of high concentrations of myeloperoxidase in the ELF of the lower respiratory tract, and a synergistic cytotoxic effect of alveolar inflammatory cells and ELF on lung epithelial cells, suggesting oxidants may play a role in causing the epithelial cell injury of this disorder.
\end{abstract}

\section{Introduction}

Idiopathic pulmonary fibrosis (IPF) ${ }^{1}$ is a chronic, often fatal inflammatory interstitial lung disorder characterized by an accumulation of alveolar macrophages and neutrophils in the lower respiratory tract, parenchymal cell injury, and fibrosis of the alveolar walls (1-7). One prominent feature of IPF is the marked changes to the alveolar epithelial cells, including destruction of type I alveolar epithelial cells and repopulation of the epithelial surface by type II alveolar epithelial cells and bronchiolar epithelial cells (8).

Alveolar macrophages and neutrophils dominate the inflammatory cell population in the lower respiratory tract of patients with IPF (9). Because both cell types are capable of inducing oxidant-mediated lung parenchymal cell cytotoxicity $(10,11)$, one mechanism to explain the epithelial cell injury associated with IPF is the spontaneous release of toxic oxidants by alveolar macrophages and neutrophils. In addition, when activated, neutrophils can also release myeloperoxidase, a 115,000-dalton pro-

Address reprint requests to Dr. Crystal, Pulmonary Branch, Building 10, Room 6D03, National Heart, Lung and Blood Institute, Bethesda, MD 20892.

Received for publication 27 October 1986.

1. Abbreviations used in this paper: EBSS, Earle's balanced salt solution; ELF, epithelial lining fluid; IPF, idiopathic pulmonary fibrosis.

The Journal of Clinical Investigation, Inc.

Volume 79, June 1987, 1665-1673 tein which can interact with $\mathrm{H}_{2} \mathrm{O}_{2}$, a product of both mononuclear phagocytes and neutrophils, to form the highly toxic hypohalide anion (12-17).

In this regard, it is reasonable to hypothesize that the alveolar epithelial cell injury that characterizes IPF may result, at least in part, from an enhanced oxidant burden that may exist in the lower respiratory tract of these patients. To evaluate this concept, inflammatory cells recovered by bronchoalveolar lavage from the lower respiratory tract of patients with IPF were evaluated for their ability to spontaneously cause oxidant-mediated alveolar epithelial cell cytotoxicity in the presence and absence of epithelial lining fluid (ELF) from the same individuals. The results indicate that inflammatory lung cells and ELF of individuals with IPF have a synergistic cytotoxic effect on lung epithelial cells that is mediated through oxidant mechanisms. Furthermore, not only are the inflammatory lung cells in IPF spontaneously releasing high levels of toxic oxidants, but the ELF markedly enhances the cytotoxic potential of the oxidants by providing a source of myeloperoxidase in the epithelial fluid lining the alveolar epithelium.

\section{Methods}

\section{Study population}

The study population consisted of 44 patients with IPF and 11 normal subjects.

$I P F$. Patients were diagnosed as having IPF according to previously defined clinical and histologic criteria (1). All individuals with IPF (24 men, 20 women) had mild or midcourse disease, the average age was $50 \pm 2 \mathrm{yr}^{2}$ and all were nonsmokers $(n=31)$ or ex-smokers $(n=13$; defined as having discontinued cigarette smoking for at least $1 \mathrm{yr}$ before initial evaluation). Of the 44 individuals, 33 were not being treated, 9 were receiving prednisone ( $30 \pm 5 \mathrm{mg}$ daily), and 2 were receiving cyclophosphamide $(120 \pm 20 \mathrm{mg}$ daily). All had chest roentgenograms that demonstrated diffuse reticulonodular infiltrates. On the average, the following lung function studies were included: vital capacity $63 \pm 4 \%$ predicted, total lung capacity $64 \pm 4 \%$ predicted, diffusing capacity $55 \pm 4 \%$ predicted, and forced expiratory volume $\left(\mathrm{FEV}_{1 \%}\right) 63 \pm 3 \%$ predicted.

Normals. 11 normal nonsmoking individuals with an average age of $23 \pm 2$ yr (eight men, three women) were evaluated. All had normal chest $\mathrm{x}$-rays and normal lung function tests.

\section{Bronchoalveolar lavage}

Each subject in this study underwent a bronchoalveolar lavage as previously described (18). Cells were separated from the supernatant by centrifugation and enumerated, and differential cell counts were determined. The total number of cells obtained was $206 \pm 18 \times 10^{3} \mathrm{cells} / \mathrm{ml}$ of lavage fluid from normal subjects and $509 \pm 79 \times 10^{3}$ cells $/ \mathrm{ml}$ from patients with IPF $(P<0.005)$. Differential cell counts of normal individuals revealed $89 \pm 2 \%$ macrophages, $11 \pm 2 \%$ lymphocytes, $1 \pm 1 \%$ neutrophils, and $0 \pm 0 \%$ eosinophils, whereas patients with IPF had $81 \pm 3 \%$ macrophages, $7 \pm 2 \%$ lymphocytes, $10 \pm 3 \%$ neutrophils, $2 \pm 1 \%$ eosinophils.

2. All data are presented as mean \pm standard error of the mean; all statistical comparisons are made using the two-tailed Student's $t$ test unless otherwise noted. 
ELF was obtained by collecting the cell-free supernatant of the lavage fluid, separating insoluble materials by centrifugation at $25,000 \mathrm{~g}$ for 15 min, and concentrating the fluid 100 -fold by pressure ultrafiltration on a YM-10 membrane (Amico Corp., Lexington, MA). All data relating to the evaluation of molecules in the ELF are expressed relative to the amount of albumin (radial immunodiffusion, Calbiochem-Behring Corp., San Diego, CA) present in the concentrated fluid.

\section{Cytotoxicity assay}

The epithelial cell strain AKD (ATCC CCL 150, American Type Culture Collection, Rockville, MD), derived from cat lung (19), previously frozen at passage 23, was used in all cytotoxicity assays. Cells were grown to confluence $\left(0.2 \pm 0.02 \times 10^{6}\right.$ per well) on 24-well culture plates (Falcon Labware, Cockeysville, MD) in Dulbecco's modified Eagle's medium (Gibco Diagnostic Laboratories, Grand Island, NY), 10\% calf serum in an atmosphere of $10 \% \mathrm{CO}_{2}, 90 \%$ air at $37^{\circ} \mathrm{C}$. The cells were labeled with ${ }^{51} \mathrm{Cr}$ (sodium chromate, $22 \mathrm{mCi} / \mu \mathrm{mol}, 1 \mathrm{ml}$ per well of $5 \mu \mathrm{Ci} / \mathrm{ml}$, Amersham Corp., Arlington Heights, IL) for $12 \mathrm{~h}$. The cells were then washed three times with phosphate-buffered saline (PBS; M. A. Bioproducts, Walkersville, MD). Serum-free medium composed of $0.5 \mathrm{ml}$ of Earle's balanced salt solution (EBSS, Biofluids Inc., Rockville, MD) was added to each well. Cytotoxicity was then assessed in the presence of media alone or various test conditions (see below) after incubation in $5 \% \mathrm{CO}_{2}$ at $37^{\circ} \mathrm{C}$ for $8 \mathrm{~h}$. Maximum releasable ${ }^{51} \mathrm{Cr}$ was assessed by incubating cells with 2\% Triton-X (Research Products International Inc., Elk Grove Village, IL), and background release of ${ }^{51} \mathrm{Cr}$ was evaluated by incubating cells in media alone. At the end of the incubation period, ${ }^{51} \mathrm{Cr}$ release in the supernatant was quantitated. Cell injury was defined in terms of a cytotoxicity index: $[(A-B) /(C-B)] \times 100$, where $A=$ disintegrations per minute (dpm) released into the media of the test sample, $B=\mathrm{dpm}$ released from control cells (i.e., background release) and $C=\mathrm{dpm}$ released from cells treated with $2 \%$ Triton-X.

\section{Lung inflammatory cell-induced epithelial cell cytotoxicity}

To evaluate the ability of lung inflammatory cells spontaneously to injure lung epithelial cells, cells recovered by lavage of normals or patients with IPF were incubated with ${ }^{51} \mathrm{Cr}$-labeled AKD cells under conditions described above. The labeled cells were incubated for $16 \mathrm{~h}$ at $37^{\circ} \mathrm{C}(0.2$ $\times 10^{6}$ per well) in $0.5 \mathrm{ml}$ EBSS plus one of the following conditions: $(a)$ $0.1 \mathrm{ml}$ EBSS (control), (b) ELF ( $0.1 \mathrm{ml}$ of 100 -fold concentrated lavage fluid containing $0.2 \mu \mathrm{g}$ of albumin), (c) $10^{6}$ inflammatory cells suspended in $0.1 \mathrm{ml}$ RPMI (M. A. Bioproducts), or (d) ELF + inflammatory cells in a total of $0.1 \mathrm{ml}$. In each of these conditions, parallel plates were incubated with $1,000 \mathrm{U}$ of catalase (an inhibitor of $\mathrm{H}_{2} \mathrm{O}_{2}$ ) or $300 \mathrm{U}$ of superoxide dismutase (an inhibitor of $\mathrm{O}_{2}^{-}$). After incubation, a cytotoxicity index was calculated as described above.

Spontaneous release of oxidants by lung inflammatory cells Spontaneous release of superoxide and hydrogen peroxide by lung inflammatory cells was assessed using ferricytochrome $c$ to detect superoxide and phenol red to detect $\mathrm{H}_{2} \mathrm{O}_{2}(20-22)$. Alveolar inflammatory cells obtained by bronchoalveolar lavage were allowed to adhere in 24-well tissue culture plates (Falcon Labware) at a concentration of $0.5 \times 10^{6}$ cells per well in Dulbecco's at $37^{\circ} \mathrm{C}, 5 \% \mathrm{CO}_{2}$, for $1 \mathrm{~h}$. The supernatant was then discarded. For the measurement of superoxide release, $0.5 \mathrm{ml}$ of Hanks' balanced salt solution (HBSS; Gibco Diagnostic Laboratories) containing $80 \mu \mathrm{M}$ ferricytochrome $c$ (type III, Sigma Chemical Co., St. Louis, MO) was added, and after incubation for $30 \mathrm{~min}$ at $37^{\circ} \mathrm{C}$, the amount of $\mathrm{O}_{2}^{-}$in the supernatant was quantified at $550 \mathrm{~nm}$. For the measurement of $\mathrm{H}_{2} \mathrm{O}_{2}$ release, HBSS containing $0.28 \mathrm{mM}$ phenol red, $8.5 \mathrm{U} / \mathrm{ml}$ horseradish peroxidase (type II, Sigma Chemical Co.) was added and after incubation for $30 \mathrm{~min}$ at $37^{\circ} \mathrm{C}$, the amount of $\mathrm{H}_{2} \mathrm{O}_{2}$ in the supernatant was quantified in the phenol red solutions after $10 \mu \mathrm{l}$ of $1 \mathrm{~N}$ $\mathrm{NaOH}$ were added to the samples and absorbance was measured spectrophotometrically at a wavelength of $610 \mathrm{~nm}$. The concentrations of hydrogen peroxide were determined according to a standard curve, using various dilutions of reagent grade $30 \% \mathrm{H}_{2} \mathrm{O}_{2}$.

\section{Measurement of myeloperoxidase and catalase in ELF}

Myeloperoxidase activity in ELF was quantitated by the $O$-dianisidine method (23). $1 \mathrm{U}$ of activity was defined as that amount of enzyme inducing a change in absorbance of the $O$-dianisidine solution equal to 0.001 absorbance $U / \mathrm{min}$ at a wavelength of $460 \mathrm{~nm}$ (15). The values of myeloperoxidase were expressed as a ratio to albumin content to account for the concentration of the lavage fluid. Catalase activity in ELF was quantified using the method described by Abei (24). $1 \mathrm{U}$ of catalase activity was defined as the rate constant of the first-order reaction, and the results were expressed as a ratio to albumin content.

\section{Purification of myeloperoxidase from neutrophils}

Myeloperoxidase was purified according to a modification of the method described by Olsen et al. (25). All reagents used were of analytical reagentgrade purity. Human leukocytes were obtained by leukapheresis of normal subjects and neutrophil granules were extracted as described by Baugh and Travis (26). The granules were sonicated (Sonifier, Ultrasonics Inc., Plainview, NY) in $0.2 \mathrm{M}$ sodium acetate, $1 \mathrm{M} \mathrm{NaCl}$ at $\mathrm{pH} 4.0$, three times for $20 \mathrm{~s}$. The granule extract was centrifuged at $30,000 \mathrm{~g}$ for 60 min and the supernatant was dialyzed against $50 \mathrm{mM}$ Tris- $\mathrm{HCl}, \mathrm{pH} 8.0$, $50 \mathrm{mM} \mathrm{NaCl}$. This material was then centrifuged $(30,000 \mathrm{~g}$ for $60 \mathrm{~min})$ and the supernatant was applied to an Elastin-Sepharose column (Pharmacia Fine Chemicals, Piscataway, NJ) equilibrated in $50 \mathrm{mM}$ Tris$\mathrm{HCl}, \mathrm{pH} 8.0,50 \mathrm{mM} \mathrm{NaCl}$. The unbound protein was collected and applied to a concanavalin A-Sepharose column (Pharmacia Fine Chemicals), equilibrated with $0.2 \mathrm{M}$ sodium acetate, $0.5 \mathrm{M} \mathrm{CaCl}_{2}, 5 \mathrm{mM}$ $\mathrm{MnCl}_{2}, 5 \mathrm{mM} \mathrm{MgCl}_{2}$, and $0.05 \%$ cetyltrimethylammonium bromide at pH 5.6. The column was washed thoroughly in the starting buffer until the optical density of the eluate was $<0.02$ absorbance $U$ at $280 \mathrm{~nm}$. The myeloperoxidase was then eluted from the column with the starting buffer containing $0.2 \mathrm{M} 1-O$-methyl $\alpha$-D-glucopyranoside. The eluted myeloperoxidase was concentrated by ultrafiltration on an Amicon YM10 membrane and applied to a Sephadex G-100 column equilibrated in starting buffer. The absorbance ratio at $430 \mathrm{~nm} / 280 \mathrm{~nm}$ of the purified myeloperoxidase was 0.82 .

\section{In vitro model of oxidant-mediated epithelial cell cytotoxicity}

In order to evaluate the mechanism(s) by which the ELF of patients with IPF might augment oxidant-mediated cytotoxicity towards lung epithelial cells, an in vitro oxidant-generating system was developed. EBSS (500 $\mu \mathrm{l})$, supplemented with $55 \mathrm{mM}$ glucose, was incubated with the cells and the production of oxidants was initiated by the addition of $0.05 \mathrm{ml}$ of glucose oxidase $(23 \mathrm{mU} / \mathrm{ml}$, Boehringer-Mannheim Biochemicals, Indianapolis, IN) to the test media and incubated at $37^{\circ} \mathrm{C}, 5 \% \mathrm{CO}_{2}$ for 8 h. At the end of the incubation period, the cytotoxicity index was determined as described above. Hydrogen peroxide produced by this system was quantitated spectrophotometrically at a wavelength of $610 \mathrm{~nm}$ by incubating $0.55 \mathrm{ml}$ of media containing $55 \mathrm{mM}$ glucose, glucose oxidase at varying concentrations, $0.95 \mathrm{ml}$ of $0.28 \mathrm{mM}$ phenol red, $8.5 \mathrm{U} / \mathrm{ml}$ horseradish peroxidase followed by $10 \mu \mathrm{l}$ of $1 \mathrm{~N} \mathrm{NaOH}$ after $60 \mathrm{~min}$ at $37^{\circ} \mathrm{C}$. Superoxide production was assessed by measuring the reduction of $0.95 \mathrm{ml}$ of $80 \mu \mathrm{M}$ ferricytochrome $c$ at $550 \mathrm{~nm}$ after $60 \mathrm{~min}$ of incubation with $0.55 \mathrm{ml}$ of the glucose, glucose-oxidase solutions. To determine whether myeloperoxidase might have a direct effect on lung epithelial cells or might augment $\mathrm{H}_{2} \mathrm{O}_{2}$-induced cytotoxicity to the lung epithelial cells, myeloperoxidase $(100 \mu l, 80 \mathrm{U} / \mathrm{ml})$ was incubated with the cells in the presence of either media alone or media and the oxidantgenerating system ( $55 \mathrm{mM}$ glucose, $23 \mathrm{mU} / \mathrm{ml}$ glucose oxidase) for $8 \mathrm{~h}$ at $37^{\circ} \mathrm{C}$, followed by determination of the cytotoxicity index.

\section{Effect of ELF of patients with IPF on augmenting epithelial cell cytotoxicity}

To determine whether ELF of patients with IPF might modulate oxidantmediated epithelial cell cytotoxicity, ELF was incubated with the lung epithelial cells in the presence or absence of the in vitro oxidant-generating system. EBSS $(500 \mu \mathrm{l})$, supplemented with $55 \mathrm{mM}$ glucose was incubated 
with the ${ }^{51} \mathrm{Cr}$-labeled AKD cells. The production of oxidants was initiated with $23 \mathrm{mU} / \mathrm{ml}$ glucose oxidase and incubated for $8 \mathrm{~h}$ at $37^{\circ} \mathrm{C}$. ELF (100 $\mu \mathrm{l}$ of concentrated lavage fluid containing $2 \mathrm{mg} / \mathrm{ml}$ albumin) from normal subjects or patients with IPF was then added to the cells in the presence or absence of the oxidant-generating system, incubated for $8 \mathrm{~h}$ at $37^{\circ} \mathrm{C}$, and the cytotoxicity index was determined as described above. To evaluate the role played by the hypohalide radical as the mechanism by which IPF ELF augmented oxidant-mediated epithelial cell cytotoxicity, the cytotoxicity index was determined using cells incubated $(8 \mathrm{~h}$ at $37^{\circ} \mathrm{C}$ ) with and without methionine $(250 \mu \mathrm{M})$, a scavenger of oxidants derived from the myeloperoxidase- $\mathrm{H}_{2} \mathrm{O}_{2}$-halide system (27) in the presence of $(a)$ the oxidant-generating system alone, $(b)$ the oxidant-generating system and myeloperoxidase $(100 \mu \mathrm{l}, 80 \mathrm{U} / \mathrm{ml})$, or $(c)$ with the oxidantgenerating system and IPF ELF $(100 \mu \mathrm{l})$. As a control for other oxidants that may play a role in this process, the cytotoxicity index was determined after the cells were incubated $\left(8 \mathrm{~h}\right.$ at $\left.37^{\circ} \mathrm{C}\right)$ in the presence of the oxidantgenerating system and $(a) \operatorname{IPF} \operatorname{ELF}(100 \mu \mathrm{l})+1,000 \mathrm{U} / \mathrm{ml}$ catalase, $(b)$ $\operatorname{IPF} \operatorname{ELF}(100 \mu \mathrm{l})+1,000 \mathrm{U} / \mathrm{ml}$ heated catalase $\left(100^{\circ} \mathrm{C}\right.$ for $\left.15 \mathrm{~min}\right),(c)$ $\operatorname{IPF} \operatorname{ELF}(100 \mu \mathrm{l})+10 \mu \mathrm{g} / \mathrm{ml}$ superoxide dismutase, $(d) \operatorname{IPF} \operatorname{ELF}(100$ $\mu \mathrm{l})+0.5 \mathrm{mM}$ sodium azide (an inhibitor of myeloperoxidase), or $(e)$ heated IPF ELF $\left(100 \mu \mathrm{l} ; 100^{\circ} \mathrm{C}\right.$ for $\left.15 \mathrm{~min}\right)$.

\section{Relationship of ELF myeloperoxidase levels to clinical outcome}

To evaluate a possible relationship between ELF myeloperoxidase levels and the clinical outcome of patients with IPF, the patients were divided into two groups at their initial evaluation, including (a) those with ELF myeloperoxidase $\leq 10 \mathrm{U} / \mathrm{mg}$ albumin (the highest level seen in normals) and $(b)$ those with ELF myeloperoxidase $>10 \mathrm{U} / \mathrm{mg}$ albumin. The patients were then reevaluated at intervals (minimum of three) over at least $1 \mathrm{yr}$ or longer after the initial evaluation. The percent absolute value (in milliliters) of the vital capacity at each interval was then used to determine the rate of change of vital capacity per year using linear regression analysis.

\section{Statistical analysis of data}

All data composed of normally distributed variables was expressed as the arithmetic mean \pm the standard error of the mean. ELF myeloperoxidase data were analyzed with the Mann-Whitney test using a twotailed 5\% significance level.

\section{Results}

Cytotoxicity induced by inflammatory lung cells and ELF of patients with IPF. The ELF, and the alveolar inflammatory cells obtained from normal subjects, were not toxic to AKD cells. In contrast, whereas the inflammatory cells of patients with IPF were only mildly toxic to the AKD cells and the ELF was not at all toxic, together the inflammatory cells and the ELF of patients with IPF clearly acted synergistically to injure lung epithelial cells (Fig. 1, $P<0.02$ vs. IPF inflammatory cells alone, IPF ELF alone, or normal inflammatory cells plus normal ELF). Although superoxide dismutase had no effect on the cytotoxicity mediated by IPF inflammatory cells + IPF ELF, when the IPF inflammatory cells in the presence of catalase were incubated with IPF ELF, the cytotoxicity index was reduced by $50 \%(P$ $<0.05)$ whereas heat-inactivated catalase $\left(100^{\circ} \mathrm{C}\right.$ for $\left.15 \mathrm{~min}\right)$ did not change the cytotoxicity index $(P>0.4)$. Furthermore, heat inactivation of IPF ELF $\left(100^{\circ} \mathrm{C}\right.$ for $\left.15 \mathrm{~min}\right)$ completely blocked its ability to enhance lung inflammatory cell-mediated cytotoxicity, and sodium azide, an inhibitor of myeloperoxidase (23), reduced the cytotoxicity index by $50 \%$, consistent with the concept that myeloperoxidase in IPF ELF may play a role in enhancing lung inflammatory cell-mediated epithelial cell injury.

Spontaneous production of oxidants by alveolar inflammatory cells. The alveolar inflammatory cells obtained from normal

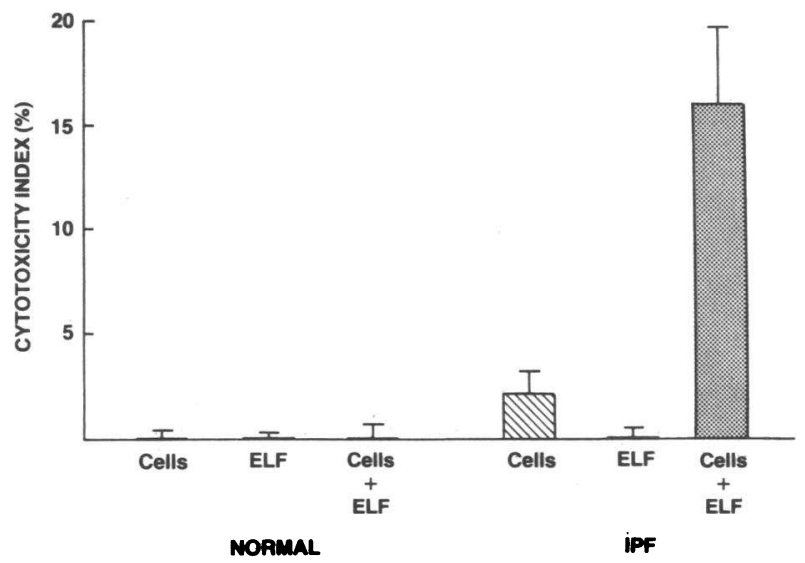

Figure 1. Alveolar inflammatory cell-induced cytotoxicity to lung epithelial cells in the presence or absence of ELF from normal subjects and patients with IPF. AKD epithelial cells served as targets. Alveolar inflammatory cells alone $\left(10^{6}\right.$ inflammatory cells $/ 0.2 \times 10^{6}$ target cells), ELF alone, or alveolar inflammatory cells + ELF were incubated with the ${ }^{51} \mathrm{Cr}$-labeled $\mathrm{AKD}$ cells at $37^{\circ} \mathrm{C}$ for $16 \mathrm{~h}$, and a cytotoxicity index was determined. Shown are the results from normals and patients with IPF.

subjects were spontaneously releasing low levels of superoxide and hydrogen peroxide. However, alveolar inflammatory cells from the lower respiratory tract of patients with IPF spontaneously released significantly more of both oxidants (Fig. 2superoxide, IPF $31.0 \pm 4.5 \mathrm{vs}$. normal $14.5 \pm 3.2 \mathrm{nmol} / 10^{6}$ cells $\cdot \mathrm{h}$, $P<0.025 ; \mathrm{H}_{2} \mathrm{O}_{2}$, IPF $7.30 \pm 0.90$ vs. normal $1.48 \pm 0.26 \mathrm{nmol} /$ $10^{6}$ cells $\left.\cdot \mathrm{h}, P<0.01\right)$.

Myeloperoxidase in ELF. The ELF of normal individuals contained little myeloperoxidase, consistent with the knowledge that neutrophils are present in only small numbers in the normal lower respiratory tract (Fig. 3). In contrast, many patients with IPF had markedly increased levels of myeloperoxidase in their ELF ( $P<0.002$, IPF vs. normal). Furthermore, serial myeloperoxidase concentrations over a minimum period of 6 mo were obtained from 11 IPF patients. All five patients with initial myeloperoxidase levels above the highest concentration seen in
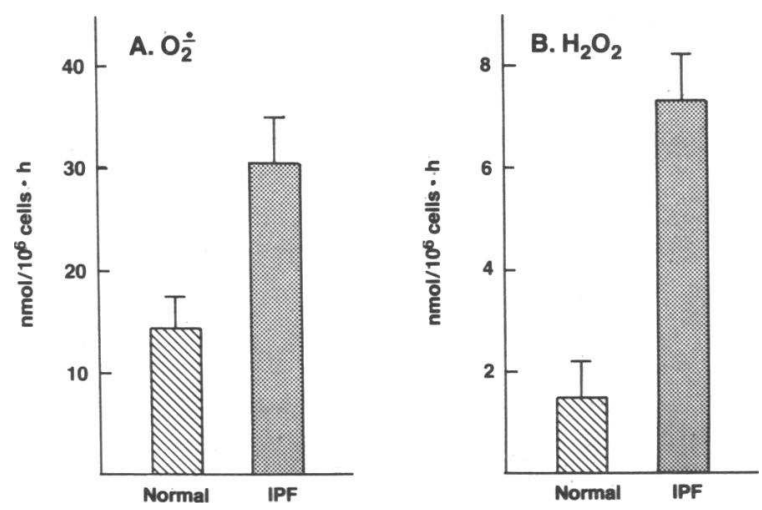

Figure 2. Spontaneous release of oxidants by alveolar inflammatory cells of normals and patients with idiopathic pulmonary fibrosis. $(A)$ Spontaneous release of $\mathrm{O}_{2}^{\dot{-}}$ over a 30 -min period. Superoxide anion was determined spectrophotometrically by the reduction of $100 \mu \mathrm{M}$ ferricytochrome $c$. (B) Spontaneous release of $\mathrm{H}_{2} \mathrm{O}_{2}$ over a 30-min period. Hydrogen peroxide was quantified by recording the oxidation of phenol red in the presence of horseradish peroxidase. 


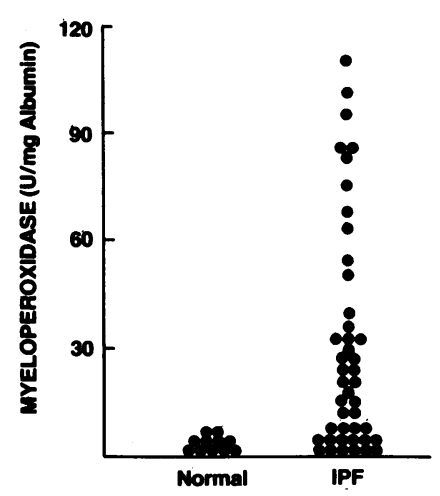

Figure 3. Myeloperoxidase in ELF obtained from normal subjects and patients with IPF. Myeloperoxidase was measured in concentrated bronchoalveolar lavage fluid by following the oxidation of $O$-dianisidine at a wavelength of $460 \mathrm{~nm}$. Albumin in the concentrated sample was quantified by radial immunodiffusion and the myeloperoxidase content of ELF of the lower respiratory tract was expressed per milligram of albumin.

control subjects (i.e., $>10 \mathrm{U} / \mathrm{mg}$ of albumin), continued to have increased levels of myeloperoxidase upon reevaluation, suggesting that the increase reflected a chronic rather than acute inflammatory event. Although the assay used for myeloperoxidase cannot distinguish among peroxidases from neutrophils, mononuclear phagocytes, or eosinophils, there was a good correlation $(r=0.66, P<0.001)$ between the level of myeloperoxidase recovered in the ELF from IPF patients and the proportion of neutrophils recovered from the same individuals.

Because neutrophils comprise a significant proportion of bronchoalveolar lavage cells obtained from the lower respiratory tract of patients with IPF, neutrophil lysis during bronchoscopy could conceivably have contributed to the observed increase in ELF myeloperoxidase concentrations. However, when supernatants of neutrophil lysates $\left(10^{6}\right.$ cells $\left./ \mathrm{ml}\right)$ and bronchoalveolar lavage cell lysates $\left(10^{6} \mathrm{cells} / \mathrm{ml}\right)$ were prepared by sonicating cells in $1 \mathrm{ml} 0.9 \% \mathrm{NaCl}$ and incubated with the $\mathrm{H}_{2} \mathrm{O}_{2}$-generating system $\left(37^{\circ} \mathrm{C}\right.$ for $\left.8 \mathrm{~h}\right)$, epithelial cell injury was suppressed rather than enhanced. This effect is likely explained by the nonspecific release of all neutrophil products including antioxidant proteins, such as catalase, during cell lysis and indicates that cell lysis during bronchoscopy is not sufficient to account for the ability of IPF ELF to enhance oxidant injury to lung epithelial cells. Thus, the presence of myeloperoxidase in the lower respiratory tract of patients with IPF is most likely a consequence of neutrophil degranulation in response to an in vivo stimulus.

Model culture system of epithelial cell cytotoxicity. The model culture system used to evaluate lung epithelial cell cytotoxicity used an artificial oxidant-generating system that produced $\mathrm{H}_{2} \mathrm{O}_{2}$ but not superoxide (Fig. $4 \mathrm{~A}$ ). Consistent with the knowledge
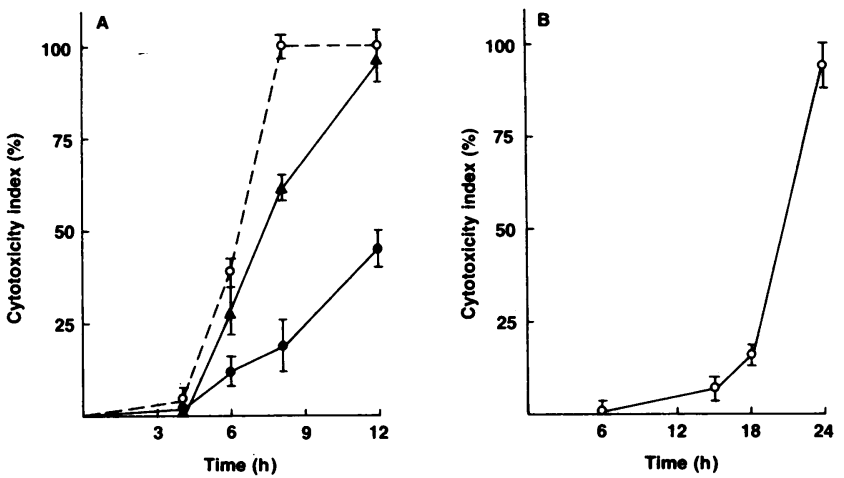

Figure 5. Time course of oxidant-mediated cytotoxicity to lung epithelial cells. $(A){ }^{51} \mathrm{Cr}$-labeled lung epithelial cells were incubated with glucose $(55 \mathrm{mM})$ and glucose oxidase $(23 \mathrm{mU} / \mathrm{ml})$ either alone (solid circles), or in the presence of myeloperoxidase $(120 \mathrm{U} / \mathrm{ml}$, triangles $)$, or IPF ELF (myeloperoxidase activity $=152 \mathrm{U} / \mathrm{mg}$ albumin, empty circles). (B) Alveolar inflammatory cell $\left(10^{6}\right.$ inflammatory cells $/ 0.2 \times 10^{6}$ target cells)-induced cytotoxicity to ${ }^{51} \mathrm{Cr}$-labeled lung epithelial cells in the presence of ELF (myeloperoxidase activity $=152 \mathrm{U} / \mathrm{mg}$ albumin) from a patient with IPF.

that $\mathrm{H}_{2} \mathrm{O}_{2}$ is cytotoxic to most cells in a concentration-dependent fashion, when increasing amounts of glucose oxidase were added to the epithelial cell cultures, an increased amount of cytotoxicity was observed (Fig. 4 B). This cytotoxicity was completely suppressed by the addition of 1000 units/ml catalase. Neither glucose nor glucose oxidase by itself was directly toxic to the epithelial cells. For all subsequent experiments, a concentration of glucose oxidase of $23 \mathrm{mU} / \mathrm{ml}$ was utilized because at this concentration either a protective or enhancing effect of ELF on oxidant mediated cytotoxicity could be detected. The incubation time used for all experiments involving the use of glucose oxidase was $8 \mathrm{~h}$ because at this time point the cytotoxicity index was greater than $90 \%$ of the maximal index (Fig. 5).

When purified myeloperoxidase was incubated with media and the cells, there was no increase in the release of ${ }^{51} \mathrm{Cr}$ above the background, indicating that in the concentrations used myeloperoxidase itself was not toxic to the cells (Fig. $4 \mathrm{C}$ ). However, whereas the $\mathrm{H}_{2} \mathrm{O}_{2}$-generating system alone induced a cytotoxicity index of $31 \pm 4 \%$, the addition of purified myeloperoxidase at a concentration within the range found in the ELF of patients with IPF $(100 \mu 1,80 \mathrm{U} / \mathrm{ml})$ enhanced the oxidant-mediated toxicity to the lung epithelial cells and brought the cytotoxicity

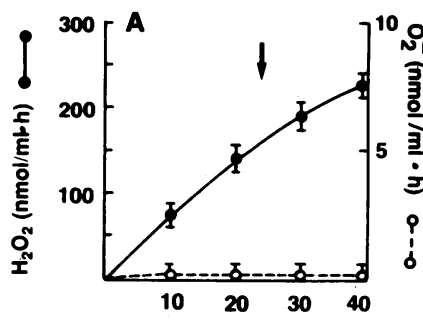

Glucose Oxidase (mU/ml)
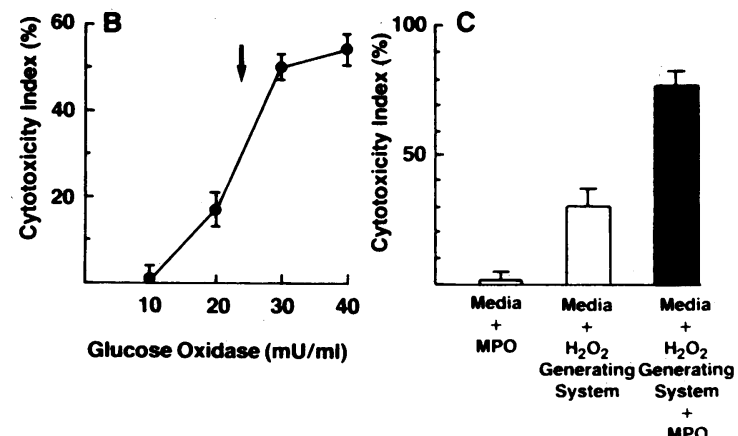

Figure 4. Characterization of a model system to evaluate the ability of lower respiratory tract ELF to modulate oxidant injury to lung epithelial cells. $(A)$ The oxidant-generating system consisted of $55 \mathrm{mM}$ glucose and increasing concentrations of glucose oxidase. The amount of $\mathrm{H}_{2} \mathrm{O}_{2}$ (expressed on the left ordinate) and superoxide anion (expressed on the right ordinate) generated in $60 \mathrm{~min}$ by increasing amounts of glucose oxidase. (B) A concentration of $23 \mathrm{mU} / \mathrm{ml}$ glucose oxidase (arrow) caused $30 \%$ cytotoxicity in $8 \mathrm{~h}$ at $37^{\circ} \mathrm{C}$ in the presence of media. $(C)$ The effect of myeloperoxidase (MPO) on the cytotoxicity of $\mathrm{AKD}$ cells. Incubations $\left(8 \mathrm{~h}\right.$ at $\left.37^{\circ} \mathrm{C}\right)$ included $\mathrm{MPO}(80 \mathrm{U} / \mathrm{ml})$ alone, the $\mathrm{H}_{2} \mathrm{O}_{2}$-generating system (glucose [55 mM], glucose oxidase [ $23 \mathrm{mU} / \mathrm{ml}$ ) alone, or the $\mathrm{H}_{2} \mathrm{O}_{2}$-generating system plus $\mathrm{MPO}$ ( $80 \mathrm{U} / \mathrm{ml}$ ). 
index to $76 \pm 4 \%(P<0.01$ compared with the oxidant-generating system alone). This cytotoxicity was completely suppressed by the addition of catalase, suggesting that both hydrogen peroxide and myeloperoxidase were necessary to produce this degree of cell injury.

Ability of ELF to modulate oxidant-mediated injury to lung epithelial cells. ELF from normal subjects and patients with IPF was not directly toxic to the lung epithelial cells (Fig. 6). When cells were incubated with the $\mathrm{H}_{2} \mathrm{O}_{2}$-generating system alone, a cytotoxicity index of $30 \% \pm 4 \%$ resulted. When the target cells were exposed to this $\mathrm{H}_{2} \mathrm{O}_{2}$-generating system in the presence of ELF from normal subjects, there was a significant reduction in the cytotoxicity index (Fig. $6, P<0.01$ ). Similarly, small amounts of IPF ELF containing myeloperoxidase $(152 \pm 11 \mathrm{U} / \mathrm{mg}$ albumin) protected the target cells against $\mathrm{H}_{2} \mathrm{O}_{2}$-induced lung epithelial cell injury, likely through the action of antioxidant molecules known to be present in ELF (see Discussion). However, increasing amounts of IPF ELF markedly enhanced the $\mathrm{H}_{2} \mathrm{O}_{2}$ mediated cytotoxicity of lung epithelial cells (Fig. 7).

Role for myeloperoxidase and the hypohalide anion in IPF oxidant-mediated lung cell injury. The ability of IPF ELF to augment $\mathrm{H}_{2} \mathrm{O}_{2}$-mediated injury to the lung parenchymal cells correlated with the concentration of myeloperoxidase in the ELF ( $r=0.68, P<0.001$; Fig. 8). In this regard, for those patients with IPF in which the ELF did not augment oxidant-mediated injury to the lung cells, the myeloperoxidase concentration of the ELF was only slightly increased above the range found in normal subjects $(10.3 \pm 2.9 \mathrm{U} / \mathrm{mg}$ of albumin). In contrast, for those IPF patients in which the ELF enhanced oxidant-mediated injury, the myeloperoxidase concentration in ELF was signifcantly increased $(32.6 \pm 10.5 \mathrm{U} / \mathrm{mg}$ of albumin, $P<0.05)$.

The ability of IPF ELF to increase the $\mathrm{H}_{2} \mathrm{O}_{2}$-mediated lung epithelial cell injury was not associated with a deficiency in the anti- $\mathrm{H}_{2} \mathrm{O}_{2}$ defenses of ELF, because the catalase content was threefold increased in IPF ELF when compared with normal ELF (433 \pm 109 vs. $154 \pm 22 \mathrm{U} / \mathrm{mg}$ of albumin, $P<0.05)$.

Further evidence that myeloperoxidase mediated the en-

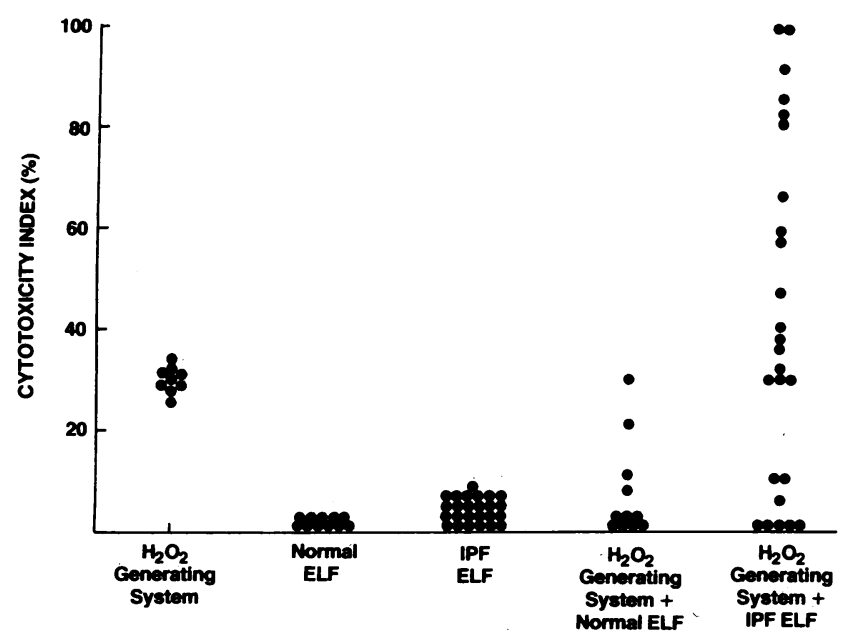

Figure 6. Effects of ELF from normal subjects and patients with IPF on the cytotoxicity of lung epithelial cells in the absence and presence of $\mathrm{H}_{2} \mathrm{O}_{2}$. The cytotoxicity index of AKD cells was measured by ${ }^{51} \mathrm{Cr}$ release. Incubations $\left(8 \mathrm{~h}\right.$ at $\left.37^{\circ} \mathrm{C}\right)$ included the $\mathrm{H}_{2} \mathrm{O}_{2}$-generating system (55 mM glucose and $23 \mathrm{mU} / \mathrm{ml}$ glucose oxidase) alone, normal ELF alone, IPF ELF alone, and $\mathrm{H}_{2} \mathrm{O}_{2}$-generating system + normal ELF, or the $\mathrm{H}_{2} \mathrm{O}_{2}$-generating system + IPF ELF.

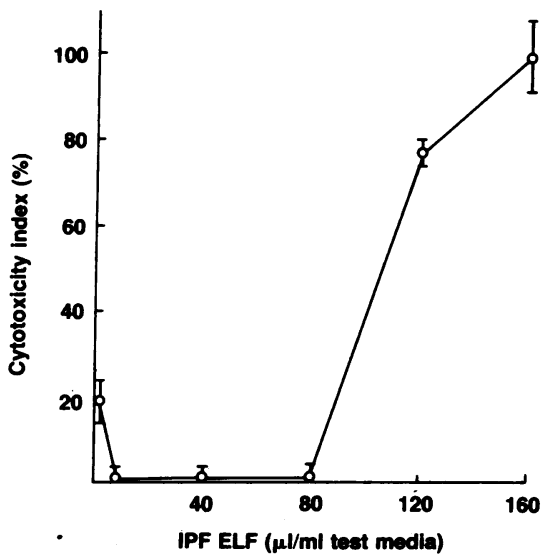

Figure 7. Effect of increasing amounts of IPF ELF on $\mathrm{H}_{2} \mathrm{O}_{2}$-mediated cytotoxicity to lung epithelial cells. ${ }^{51} \mathrm{Cr}$-labeled lung epithelial cells were incubated $\left(8 \mathrm{~h}\right.$ at $\left.37^{\circ} \mathrm{C}\right)$ with glucose $(55 \mathrm{mM})$ and glucose oxidase $(23 \mathrm{mU} / \mathrm{ml})$ alone or in the presence of increasing amounts of ELF (myeloperoxidase activity, $76 \pm 6 \mathrm{U} / \mathrm{ml}$ ELF) from a patient with IPF.

hancement of oxidant injury to lung epithelial cells by IPF ELF was provided by the observations that $(a)$ whereas the oxidantgenerating system plus IPF ELF caused a cytotoxicity index of $72 \pm 3 \%$, catalase completely inhibited IPF ELF-mediated cytotoxicity $(0 \pm 1 \%, P<0.001)$ while heat-inactivated catalase had no effect $(64 \pm 4 \%, P<0.2)$, (b) superoxide dismutase did not suppress the IPF ELF-mediated cytotoxicity $(72 \pm 2 \%, P<0.5)$; (c) azide, an inhibitor of myeloperoxidase, was partially protective (42 $\pm 2 \%, P<0.01) ;(d)$ heating the IPF ELF suppressed its ability to enhance the oxidant-mediated epithelial cell injury (14 $\pm 3 \%, P<0.001$ ); and $(e)$ when purified human myeloperoxidase was added to ELF that did not augment $\mathrm{H}_{2} \mathrm{O}_{2}$-mediated injury (final concentration $60 \mathrm{U} / \mathrm{mg}$ of albumin), the ELF markedly increased the epithelial cell injury (cytotoxic index

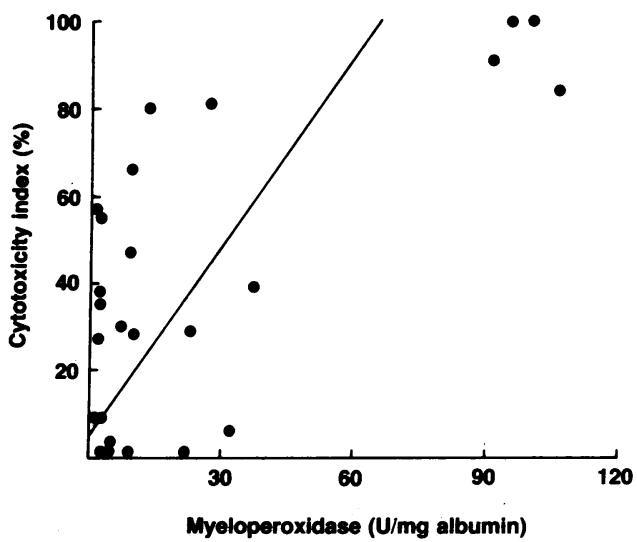

Figure 8. Correlation between the myeloperoxidase concentration of ELF from patients with IPF and the capacity of IPF ELF to enhance oxidant-mediated epithelial cell injury. Myeloperoxidase was determined by reacting ELF with hydrogen peroxide and $O$-dianisidine for $15 \mathrm{~min}$ and stopping the reaction with sodium azide. Absorbance of the reaction mixture was measured spectrophotomethically at a wavelength of $460 \mathrm{~nm}$. The cytotoxicity index was determined after incubating $\left(8 \mathrm{~h}\right.$ at $\left.37^{\circ} \mathrm{C}, 10 \% \mathrm{CO}_{2}\right){ }^{51} \mathrm{Cr}$-labeled lung epithelial cells with an $\mathrm{H}_{2} \mathrm{O}_{2}$-generating system (glucose, glucose-oxidase) and IPF ELF, by measuring the amount of ${ }^{51} \mathrm{Cr}$ released in the culture supernatant. 
before myeloperoxidase, $0 \pm 3 \%$; after myeloperoxidase $70 \pm 3 \%$, $P<0.001$ ).

Because the major mechanism by which myeloperoxidase effects injury is through its ability to convert (in the presence of a halide) $\mathrm{H}_{2} \mathrm{O}_{2}$ to the very toxic hypohalide radical, it is reasonable to hypothesize that the ability of IPF ELF to augment $\mathrm{H}_{2} \mathrm{O}_{2}$ mediated injury to lung epithelial cells is through the hypohalide anion. In this context, the cytotoxicity studies were repeated in the presence or absence of methionine, a scavenger of products of the myeloperoxidase system (27). Whereas the hydrogen peroxide-generating system alone induced a cytotoxicity index of $25 \pm 3 \%$, methionine was unable to lower the index. However, in the presence of either purified myeloperoxidase or ELF from patients with IPF, where the cytotoxicity of the hydrogen peroxide generating system was markedly enhanced, the addition of methionine completely suppressed the lung cell injury (Fig. 9).

Correlation of ELF myeloperoxidase concentrations and functional outcome of patients with IPF. 18 patients with IPF underwent multiple respiratory physiologic determinations over an interval of at least $1 \mathrm{yr}$ after ELF myeloperoxidase concentrations had been quantitated. Of these patients, eight had myeloperoxidase concentrations within the range found in normal subjects ( $\leq 10 \mathrm{U} / \mathrm{mg}$ of albumin) and $10 \mathrm{had}$ increased levels of ELF myeloperoxidase ( $>10 \mathrm{U} / \mathrm{mg}$ of albumin). Strikingly, the rate of deterioration of the vital capacity was more rapid in those patients with increased ELF myeloperoxidase than in those patients with low levels of ELF myeloperoxidase ( $-397 \pm 100$ vs. $-44 \pm 50 \mathrm{ml} / \mathrm{yr} P<0.05$, Fig. 10).

\section{Discussion}

IPF is characterized by marked alterations in the normal alveolar epithelium consisting of a loss of type I epithelial cells and replacement by cuboidal, often metaplastic cells $(1,8,28-33)$. Although the mechanisms by which the epithelium attempts to repair itself are unknown, the intensity of inflammation occurring in the alveolar structures of these patients suggests that in-

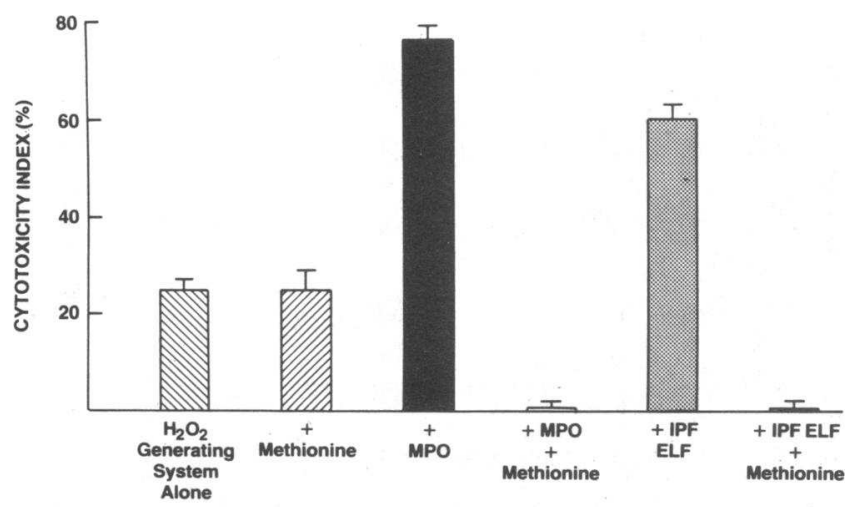

Figure 9. Characterization of the ability of methionine, an inhibitor of the hypohalide anion, to suppress the cytotoxicity of lung epithelial cells mediated by $\mathrm{H}_{2} \mathrm{O}_{2}$ and ELF of patients with IPF. Lung epithelial cells (AKD) were incubated $\left(8 \mathrm{~h}\right.$ at $\left.37^{\circ} \mathrm{C}\right)$ in the presence of an $\mathrm{H}_{2} \mathrm{O}_{2-}$ generating system ( $55 \mathrm{mM}$ glucose, $23 \mathrm{mU} / \mathrm{ml}$ glucose oxidase) alone or together with methionine $(250 \mu \mathrm{M})$, myeloperoxidase (MPO, $80 \mathrm{U} /$ $\mathrm{ml}), \mathrm{MPO}+$ methionine, ELF from patients with IPF or ELF from patients with IPF + methionine. Cells were incubated at $37^{\circ} \mathrm{C}, 5 \%$ $\mathrm{CO}_{2}$ for $\mathbf{8} \mathrm{h}$ and the cytotoxicity index was determined.

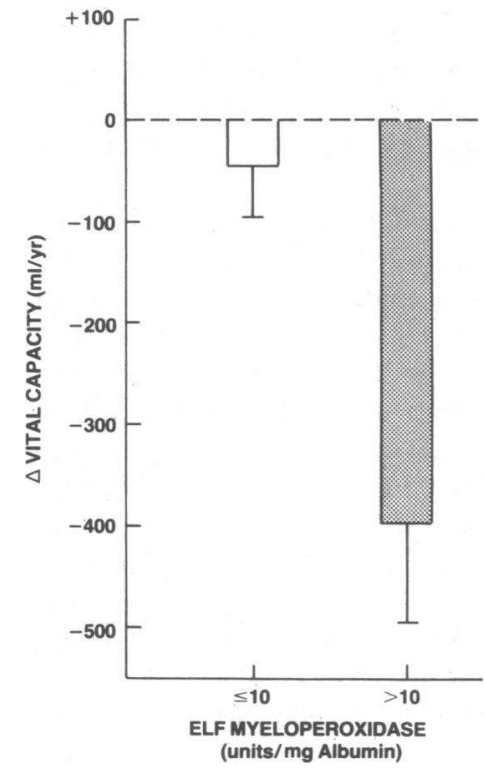

Figure 10. Relationship of the concentration of myeloperoxidase in the ELF of the lower respiratory tract of patients with IPF and the rate of change of the vital capacity over time. At the time of initial evaluation, the concentration of myeloperoxidase in the ELF was quantified (per milligram of albumin) and the patient population with IPF was divided into two groups: (a) ELF myeloperoxidase $\leq 10$ $\mathrm{U} / \mathrm{mg}$ of albumin; and $(b)$ ELF myeloperoxidase $>10$ $\mathrm{U} / \mathrm{mg}$ of albumin. The vital capacity was measured at the time of initial evaluation and again for at least three determinations over a minimum time of $1 \mathrm{yr}$ after the initial measurements. The change in vital capacity per year (milliliters per year) is expressed on the ordinate for the two groups. The separation of the two groups at an ELF myeloperoxidase level of 10 $\mathrm{U} / \mathrm{mg}$ of albumin was chosen because this level represents the highest level found in normal subjects (see Fig. 2).

flammatory cell-mediated oxidant injury may play a role in the initial injury to the normal alveolar epithelium. Consistent with this hypothesis, this study demonstrates that the inflammatory cells that accumulate on the alveolar surface in IPF spontaneously release increased amounts of the oxidants $\mathrm{O}_{2}^{-}$and $\mathrm{H}_{2} \mathrm{O}_{2}$ and, in the presence of their alveolar ELF, can induce lung epithelial cell inury likely through a myeloperoxidase-mediated hypohalide radical related process. Several lines of evidence suggest that the epithelial cell injury induced by IPF lung inflammatory cells and ELF was related to oxidants derived from the $\mathrm{H}_{2} \mathrm{O}_{2}$-myeloperoxidase reaction: (a) catalase, but not heat-inactivated catalase, reduced the cytotoxicity, suggesting that the effect of catalase was related to $\mathrm{H}_{2} \mathrm{O}_{2}$ degradation rather than a nonspecific effect such as alteration of inflammatory cell adherence to the target cells; $(b)$ heat inactivation of IPF ELF blocked its cytotoxicity enhancing effect, suggesting that the ELF-induced injury was related to enzymatic activity; $(c)$ addition of a myeloperoxidase inhibitor to IPF ELF markedly reduced its ability to enhance inflammatory cell-mediated cytotoxicity; and $(d)$ inflammatory lung cells from patients with IPF spontaneously released increased amounts of $\mathrm{O}_{2}^{-}$and $\mathrm{H}_{2} \mathrm{O}_{2}$.

Evidence of epithelial cell injury in IPF. A variety of observations at the optical and electron-microscopic levels have demonstrated that prominent alveolar epithelial cell injury is a characteristic feature of IPF $(1,8,28-33)$. First, although type I pneumocytes comprise $40 \%$ of the alveolar epithelial cell population and over $90 \%$ of the alveolar surface in normal lung (34), in IPF they are markedly decreased in areas of severe inflammation, suggesting that extensive injury and death of the type I pneumocyte has occurred $(1,8,31,32)$. Second, hyperplasia of the type II pneumocyte, as recognized by increased numbers of cells and mitotic figures within the cells, is a hallmark of the histologic features of IPF $(1,8,28,29,31-33)$. Current concepts are that this hyperplasia represents a process of regeneration of the epithelial surface that has been damaged $(8,29$, 
32). In addition to hyperplasia, the type II cells show morphologic signs of injury as evidenced by an attenuated cytoplasm, increased numbers of microvilli, lamellar inclusion bodies (31), and desquamation into the alveolar space $(8,31,32)$. In areas of most severe damage, the type II cells are replaced by cuboidal epithelial cells of bronchial origin, indicating death of both type I and type II pneumocytes $(1,8,31)$.

Mechanisms of epithelial cell injury in IPF. Together, the present investigation and a variety of diverse in vivo and in vitro studies are consistent with the concept that alveolar epithelial cell injury in IPF is mediated through inflammatory cell produced oxidants. First, experimental animal studies with the intratracheal instillation of either oxidant-generating enzyme systems (35-37) or neutrophil activators, such as phorbol myristate acetate (36-38), formylated norleu-leu-phe $(36,37)$, and immune complexes $(39,40)$, have demonstrated that an oxidant burden in the lower respiratory tract results in severe lung parenchymal cell damage that includes damage to alveolar epithelial cells, epithelial cell death, and desquamation (35-38). Furthermore, these changes are followed by the appearance of severe interstitial fibrosis $(35,38)$, suggesting that oxidants can initiate lung parenchymal changes similar to the histologic changes characteristic of IPF.

Second, IPF is characterized by an accumulation of inflammatory cells in the lower respiratory tract $(1,9,28-31,41)$, including alveolar macrophages, neutrophils, and eosinophils, all of which are capable of producing oxidants $(20,42-48)$.

Third, inflammatory cells recovered from the lower respiratory tract of patients with IPF are spontaneously releasing increased amounts of $\mathrm{O}_{2}^{-}$and $\mathrm{H}_{2} \mathrm{O}_{2}$. Because these cells are present in increased numbers in the lower respiratory tract of patients with IPF $(1,9,41)$, it is likely that the oxidant burden at the alveolar epithelial surface is increased manyfold over normal. Although the mechanisms responsible for the increased oxidant release by IPF alveolar inflammatory cells are not known, it has been documented that immune complexes are present in the lungs of patients with IPF (49-51). In that immune complexes are a potent stimulus of oxidant production by macrophages, neutrophils, and eosinophils $(42,52-54)$, it is reasonable to conclude that immune complexes may contribute to the enhanced lung inflammatory cell release of oxidants in the lower respiratory tract of these patients.

Fourth, peroxidase activity was found in increased amounts in the ELF of the majority of patients with IPF. Although the source of the peroxidase is unknown, the significant correlation between the amount of ELF peroxidase activity and the number of neutrophils recovered from the lower respiratory tract suggests that most of the peroxidase activity was derived from neutrophils, cells known to have large amounts of myeloperoxidase (13). This concept is consistent with the knowledge that immune complexes $(53,55)$ and neutrophil chemotactic factors $(51)$, both present in the lungs of patients with IPF (49-51), are potent stimuli of neutrophil degranulation, including the release of myeloperoxidase $(53,55,56)$. Furthermore, other neutrophil granule products, including collagenase and neutral proteinases, are present in IPF ELF (57), consistent with the concept that neutrophil degranulation occurs in the lower respiratory tract of these patients and that the peroxidase activity detected in IPF ELF is likely of neutrophil origin.

Fifth, the knowledge that $(a)$ there is an increased spontaneous release of $\mathrm{H}_{2} \mathrm{O}_{2}$ from lung inflammatory cells of patients with IPF, $(b)$ there is a high concentration of myeloperoxidase in their ELF, and (c) myeloperoxidase can convert $\mathrm{H}_{2} \mathrm{O}_{2}$ in the presence of a halide to the very toxic hypochloride anion (5862) is consistent with the concept that the hypochloride anion is likely generated at the alveolar epithelial surface in IPF and contributes to the lung epithelial cell injury. Evidence supporting such a mechanism is the in vitro demonstration that alveolar inflammatory cells of patients with IPF act synergistically with IPF ELF to markedly enhance the cytotoxicity towards lung epithelial cells (Fig. 7), which is in makred contrast with the antioxidant protective effect known to be present in the ELF of normal subjects $(63,64)$.

The mechanism by which normal ELF protects lung cells against $\mathrm{H}_{2} \mathrm{O}_{2}$ is through conversion of $\mathrm{H}_{2} \mathrm{O}_{2}$ to $\mathrm{H}_{2} \mathrm{O}$ by catalase (46). However, the enhanced oxidant injury induced by IPF ELF was not associated with a deficiency of antioxidants, because the catalase concentration of IPF ELF was consistently two to three times the concentration of catalase in normal ELF. No significant difference in catalase concentration was found between IPF ELF that decreased $\mathrm{H}_{2} \mathrm{O}_{2}$ cytotoxicity and IPF ELF that increased the cytotoxicity. Furthermore, the addition of purified human myeloperoxidase to IPF ELF that did not spontaneously enhance oxidant cytotoxicity provided the ELF with the capacity to markedly enhance $\mathrm{H}_{2} \mathrm{O}_{2}$-mediated cytotoxicity. These studies suggest that myeloperoxidase can overwhelm the antioxidant properties of ELF and mediate lung cell damage.

The concept that the hypohalous anion generated at the alveolar epithelial surface in IPF may contribute to the lung epithelial cell injury is supported by the knowledge that myeloperoxidase is capable of markedly increasing the cytotoxicity of $\mathrm{H}_{2} \mathrm{O}_{2}$ for a variety of mammalian cells $(15-17,58-62)$ including lung parenchymal cells (35).

Many pieces of evidence suggest that the oxidant-mediated cytotoxicity enhancing characteristics of IPF ELF are related to the generation of hypohalous anion. First, the cytotoxicity-enhancing properties of IPF ELF were dependent on the presence of $\mathrm{H}_{2} \mathrm{O}_{2}$ but not $\mathrm{O}_{2}^{-}$, in that superoxide dismutase did not alter the cytotoxicity. Second, IPF ELF myeloperoxidase levels showed a significant correlation with the cytotoxic potential of ELF. Third, heat-inactivating the IPF ELF markedly reduced its cytotoxic potential, as did sodium azide, a potent myeloperoxidase inhibitor, suggesting that myeloperoxidase mediated the oxidant-enhancing properties of IPF ELF. Fourth, the oxidants produced by the reaction of $\mathrm{H}_{2} \mathrm{O}_{2}$ and myeloperoxidase include singlet oxygen and the hypohalous anion, however, at $\mathrm{pH} 7.4$ only the hypohalous anion is produced in detectable amounts (65). Finally, methionine, a known scavenger of the hypohalous anion, provided the epithelial cells with complete protection against the IPF ELF. Together, these data suggest that the mechanisms by which IPF ELF increase epithelial cell cytotoxicity likely relate to the formation of the highly reactive hypohalous anion. This toxic radical is capable of oxidizing a variety of sites in molecules, including sulfhydryl groups, thioethers such as methionine, aromatic and nitrogenous compounds, porphyrins, and nucleotides, resulting in alterations of critical cellular components and cell death $(27,66-68)$. Because IPF ELF is capable of markedly increasing the cytotoxic potential of $\mathrm{H}_{2} \mathrm{O}_{2}$ for lung epithelial cells through mechanisms related to myeloperoxidase, it is likely that toxic radicals derived from the $\mathrm{H}_{2} \mathrm{O}_{2}$-myeloperoxidase-halide system contribute, at least in part, to the severe epithelial cell injury characteristic of IPF. Consistent with this concept is the observation that patients with high ELF myeloperoxidase concentrations have a more rapid rate of functional 
deterioration, as shown by an accelerated annual rate of decline in their vital capacity, than do patients with low levels of ELF myeloperoxidase.

In the context of the above, it is reasonable to conclude that alveolar epithelial cell injury in IPF is likely mediated, at least in part, by oxidants generated by the $\mathrm{H}_{2} \mathrm{O}_{2}$-myeloperoxidasehalide reaction at the alveolar epithelial surface. In this regard, strategies to reduce the oxidant burden in IPF may be beneficial in decreasing alveolar epithelial cell injury and consequently reduce the progressive deterioration of these patients.

\section{Acknowledgments}

We thank Dr. James E. Gadek for helpful discussions. Dr. Cantin was partially supported by a fellowship from l'Institut de Recherche en Santé et en Sécurité du Travail au Québec.

\section{References}

1. Crystal, R. G., J. D. Fulmer, W. C. Roberts, M. L. Moss, B. R. Line, and H. Y. Reynolds. 1976. Idiopathic pulmonary fibrosis: clinical, histologic, radiologic, physiologic, scintigraphic, cytological and biochemical aspects. Ann. Intern. Med. 85:769-788.

2. Hamman, L., and A. R. Rich. 1944. Acute diffuse interstitial fibrosis of the lungs. Bull. Johns Hopkins Hosp. 74:177-212.

3. Herbert, F. A., B. B. Nahmias, E. A. Gaensler, and H. E. MacMahon. 1962. Pathophysiology of interstitial pulmonary fibrosis: report of 19 cases and follow-up with corticosteroids. Arch. Intern. Med. 110:628-648.

4. Fulmer, J. D., and R. G. Crystal. 1976. The biochemical basis of pulmonary function. In The Biochemical Basis of Pulmonary Function. R. G. Crystal, editor. Marcel Dekker, Inc., New York. 419-466.

5. Fulmer, J. D., W. C. Roberts, E. R. von Gal, and R. G. Crystal. 1977. Small airways in idiopathic pulmonary fibrosis: comparison of morphologic and physiologic observations. J. Clin. Invest. 60:595-610.

6. Crystal, R. G., J. D. Fulmer, B. J. Baum, J. Bernardo, K. H. Bradley, S. D. Bruel, N. A. Elson, G. A. Fells, V. J. Ferrans, J. E. Gadek, G. W. Hunninghake, O. Kawanami, J. A. Kellman, B. R. Line, J. A. McDonald, B. D. McLees, W. C. Roberts, D. M. Rosenberg, P. Tolstoshev, E. von Gal, and S. E. Weinberger. 1978. Cells, collagen and idiopathic pulmonary fibrosis. Lung. 155:199-224.

7. Fulmer, J. D., W. C. Roberts, E. R. von Gal, and R. G. Crystal. 1979. Morphologic-physiologic correlates of the severity of fibrosis and degree of cellularity in idiopathic pulmonary fibrosis. J. Clin. Invest. 63: 665-676.

8. Kawanami, O., V. J. Ferrans, and R. G. Crystal. 1982. Structure of alveolar epithelial cells in patients with fibrotic lung disorders. Lab. Invest. 46:39-53.

9. Reynolds, H. Y., J. D. Fulmer, J. A. Kazmierowski, W. C. Roberts, M. M. Frank, and R. G. Crystal. 1977. Analysis of cellular and protein content of broncho-alveolar lavage fluid from patients with idiopathic pulmonary fibrosis and chronic hypersensitivity pneumonitis. J. Clin. Invest. 59:165-175.

10. Nathan, C. F., L. H. Bruckner, S. C. Silverstein, and Z. A. Cohn. 1979. Extracellular cytolysis by activated macrophages and granulocytes. I. Pharmacologic triggering effector cells and the release of hydrogen peroxide. J. Exp. Med. 149:84-99.

11. Nathan, C. F., S. C. Silverstein, L. H. Bruckner, and Z. A. Cohn. 1979. Extracellular cytolysis by activated macrophages and granulocytes. II. Hydrogen peroxide as a mediator of cytotoxicity. J. Exp. Med. 149: 100-113.

12. Klebanoff, S. J., R. A. Clark, and H. Rosen. 1976. Myeloperoxidase mediated cytotoxicity. In Cancer Enzymology. J. Schultz, and F. Ahmad, editors. Academic Press, Inc., New York. 267-288.

13. Klebanoff, S. J., and R. A. Clark. 1978. The neutrophil: function and clinical disorders. S. J. Klebanoff, and R. A. Clark, editors. Elsevier/ North Holland, Amsterdam. 44-48.
14. Klebanoff, S. J., and C. B. Hamon. 1972. Role of myeloperoxidasemediated antimicrobial systems in intact leukocytes. J. Reticuloendothel. Soc. 12:170-196.

15. Klebanoff, S. J., and R. A. Clark. 1975. Hemolysis and iodination of erythrocyte components by a myeloperoxidase-mediated system. Blood. 45:699-707.

16. Clark, R. A., S. J. Klebanoff, A. B. Einstein, and A. Fefer. 1975. Peroxidase- $\mathrm{H}_{2} \mathrm{O}_{2}$-halide system: cytotoxicity effect on mammalian tumor cells. Blood. 45:161-170.

17. Clark, R. A., and S. J. Klebanoff. 1977. Myeloperoxidase- $\mathrm{H}_{2} \mathrm{O}_{2-}$ halide system: cytotoxic effect on human blood leukocytes. Blood. 50: 65-70.

18. Hunninghake, G. W., J. E. Gadek, O. Kawanami, V. J. Ferrans, and R. G. Crystal. 1979. Inflammatory and immune processes in the human lung in health and in disease: evaluation by bronchoalveolar lavage. Am. J. Pathol. 97:149-205.

19. Kniazeff, A. J., G. D. Stoner, L. Terry, R. M. Wagner, and R. D. Hoppenstand. 1976. Characteristics of epithelial cells cultured from feline lung. Lab. Invest. 34:495-500.

20. Hoidal, J. R., R. B. Fox, P. A. Lemarbe, R. Perri, and J. E. Repine. 1981. Altered oxidative metabolism responses in vitro of alveolar macrophages from asymptomatic smokers. Am. Rev. Respir. Dis. 123 85-89.

21. Pick, E., and Y. Keisari. 1980. A simple colorimetric method for the measurement of hydrogen peroxide produced by cells in culture. $J$. Immunol. Methods. 38:161-170.

22. Pick, E., and Y. Keisari. 1981. Superoxide anion and hydrogen peroxide production by chemically elicited peritoneal macrophages: induction by multiple nonphagocytic stimuli. Cell. Immunol. 59:301-318.

23. Worthington Enzyme Manual. 1972. Worthington Biochemical Corp., Freehold, NJ. 43.

24. Aebi, H. 1984. Catalase in vitro. Methods in Enzymol. 105:121126.

25. Olsen, R. L., and C. Little. 1983. Purification and some properties of myeloperoxidase and eosinophil peroxidase from human blood. Biochem. J. 209:781-787.

26. Baugh, R. J., and J. Travis. 1976. Human leukocyte granule elastase: rapid isolation and characterization. Biochemistry. 15:836-841.

27. Tsan, M. F., and J. W. Chen. 1980. Oxidation of methionine by human polymorphonuclear leukocytes. J. Clin. Invest. 65:1041-1050.

28. Valdivia, E., G. Hensley, J. Wu, E. P. LeRoy, and W. Jaeschke. 1977. Morphology and pathogenesis of desquamative interstitial pneumonitis. Thorax. 32:7-18.

29. Spencer, H. 1967. Interstitial pneumonia. Annu. Rev. Med. 18 $423-442$.

30. Carrington, C. B. 1968. Organizing interstitial pneumonia: definition of the lesion and attempts to devise an experimental model. Yale J. Biol. Med. 40:353-363.

31. Coalson, J. J. 1982. The ultrastructure of human fibrosing alveolitis. Virchows Arch. Abt. A. Pathol. Anat. 395:181-199.

32. Shortland, J. R., C. S. Darke, and W. J. A. Crane. 1969. Electron microscopy of desquamative interstitial pneumonia. Thorax. 24:192208.

33. Leibow, A. A., A. Steer, and J. G. Billingsley. 1965. Desquamative interstitial pneumonia. Am. J. Med. 39:369-404.

34. Kuhn, C. 1976. The cells of the lung and their organelles. In The Biochemical Basis of Pulmonary Function. R. G. Crystal, editor. Marcel Dekker, Inc., New York. 3-48.

35. Johnson, K. J., J. C. Fantone, J. Kaplan, and P. A. Ward. 1981. In vivo damage of rat lungs by oxygen metabolites. J. Clin. Invest. 67 : 983-993.

36. Schraufstätter, I., S. D. Revak, and C. G. Cochrane. 1984. Biochemical factors in pulmonary inflammatory disease. Fed. Proc. 43:28072810.

37. Schraufstätter, I. V., S. D. Revak, and C. G. Cochrane. 1984. Proteases and oxidants in experimental pulmonary inflammatory injury. J. Clin. Invest. 73:1175-1184.

38. Johnson, K. J., and P. A. Ward. 1982. Acute and progressive 
lung injury after contact with phorbol myristate acetate. Am. J. Pathol. 107:29-35.

39. Johnson, K. J., and P. A. Ward. 1980. Role of oxygen metabolites in immune complex injury of lung. J. Immunol. 126:2365-2374.

40. Daniele, R. P., P. M. Henson, J. C. Fantone, P. A. Ward, and R. B. Dreisin. 1981. Immune complex injury of the lung. Am. Rev. Respir. Dis. 124:738-755.

41. Haslam, P. L., C. W. G. Turton, and B. Heard. 1980. Bronchoalveolar lavage in pulmonary fibrosis: comparison of cells obtained with lung biopsy and clinical features. Thorax. 35:9-18.

42. Ward, P. A., R. E. Duque, M. C. Sulavik, and K. J. Johnson. 1983. In vitro and in vivo stimulation of rat neutrophils and alveolar macrophages by immune complexes: production of $\mathrm{O}_{2}^{\dot{\bar{*}}}$ and $\mathrm{H}_{2} \mathrm{O}_{2}$. Am. J. Pathol. 110:297-309.

43. Johnston, R. B., C. A. Godzik, and Z. A. Cohn. 1978. Increased superoxide production by immunologically activated and chemically elicited macrophages. J. Exp. Med. 148:115-127.

44. Klebanoff, S. J. 1980. Oxygen metabolism and the toxic properties of phagoyctes. Ann. Intern. Med. 93:480-489.

45. Babior, B. M. 1978. Oxygen-dependent microbial killing by phagocytes. Parts I and II. N. Engl. J. Med. 298:659-668; 721-725.

46. Badwey, J. A., and M. L. Karnovsky. 1980. Active oxygen species and the functions of phagocytic leukocytes. Annu. Rev. Biochem. 49: 695-726.

47. Dechatelet, L. R., R. A. Migler, P. S. Shirley, D. A. Bass, and C. E. McCall. 1978. Enzymes of oxidative metabolism in the human eosinophil. Proc. Soc. Exp. Biol. Med. 158:537-541.

48. Davis, W. B., G. A. Fells, X. H. Sun, J. E. Gadek, A. Venet, and R. G. Crystal. 1984. Eosinophil mediated injury to lung parenchymal cells and interstitial matrix: a possible role for eosinophils in chronic inflammatory disorders of the lower respiratory tract. J. Clin. Invest. 74 269-278.

49. Dreisen, R. B., M. I. Schwarz, A. N. Theofilopoulos, and R. E. Stanford. 1978. Circulating immune complexes in the idiopathic interstitial pneumonias. $N$. Engl. J. Med. 298:353-357.

50. Turner-Warwick, M. 1974. Immunologic aspects of systemic diseases of the lungs. Proc. $R$. Soc. Med. 67:541-547.

51. Hunninghake, G. W., J. E. Gadek, T. J. Lawley, and R. G. Crystal. 1981. Mechanisms of neutrophil accumulation in the lungs of patients with idiopathic pulmonary fibrosis. J. Clin. Invest. 68:259-269.

52. Goldstein, I. M., D. Roos, H. B. Kaplan, and G. Weissmann. 1975. Complement and immunoglobulins stimulate superoxide production by human leukocytes independently of phagocytosis. J. Clin. Invest. 56:1155-1163.

53. Weissmann, G., J. E. Smolen, and H. M. Korchak. 1980. Release of inflammatory mediators from stimulated neutrophils. N. Engl. J. Med. 303:27-34.

54. Weiss, S. J., and P. A. Ward. 1982. Immune complex induced generation of oxygen metabolites by human neutrophils. J. Immunol. 129:309-313.
55. Henson, P. M., H. B. Johnson, and H. L. Spiegleberg. 1972. The release of granule enzymes from human neutrophils stimulated by aggregated immunoglobulins of different classes and subclasses. J. Immunol. 109:1182-1192.

56. Henson, P. M. 1971. The immunologic release of constituents from neutrophil leukocytes. I. The role of antibody and complement on nonphagocytosable surfaces or phagocytosable particles. J. Immunol. 107: 1535-1546.

57. Gadek, J. E., J. A. Kelman, G. A. Fells, S. E. Weinberger, A. L. Horwitz, H. Y. Reynolds, J. D. Fulmer, and R. G. Crystal. 1979. Collagenase in the lower respiratory tract of patients with idiopathic pulmonary fibrosis. N. Engl. J. Med. 301:737-742.

58. Clark, R. A., and S. J. Klebanoff. 1975. Neutrophil-mediated tumor cell cytotoxicity: role of the peroxidase system. J. Exp. Med. 141: 1442-1447.

59. Clark, R. A., and S. J. Klebanoff. 1979. Role of the myeloperoxidase $\mathrm{H}_{2} \mathrm{O}_{2}$ halide system in concanavalin A-induced tumor cell killing by human neutrophils. J. Immunol. 122:2605-2610.

60. Clark, R. A., and S. Szot. 1981. The myeloperoxidase hydrogen peroxide halide system as effector of neutrophil mediated tumor cell cytotoxicity. J. Immunol. 126:1295-1301.

61. Slivka, A., A. F. LoBuglio, and S. J. Weiss. 1980. A potential role for hypochlorous acid in granulocyte-mediated tumor cell cytotoxicity Blood. 55:347-350.

62. Weiss, S. J., and A. Slivka. 1982. Monocyte and granulocytemediated tumor destruction: a role for the hydrogen peroxide myeloperoxidase chloride system. J. Clin. Invest. 69:255-262.

63. Cantin, A., G. Fells, J. T. Given, and R. G. Crystal. 1983. Antioxidant protection of the lower respiratory tract by components of epithelial lining fluid. Clin. Res. 31:511A. (Abstr.)

64. Cantin, A., L. North, and R. G. Crystal. 1985. Glutathione is present in normal alveolar epithelial lining fluid in sufficient concentration to provide antioxidant protection to lung parenchymal cells. Am. Rev. Respir. Dis. 131:A372.

65. Karnofsky, J. R., J. Wright, G. E. Miles-Richardson, and A. I. Tauber. 1984. Biochemical requirements for singlet oxygen production by purified myeloperoxidase. J. Clin. Invest. 74:1489-1495.

66. Turkall, R. M., and M. F. Tsan. 1982. Oxidation of glutathione by the myeloperoxidase system. Res. J. Reticuloendothel. Soc. 31:353360.

67. Zgliczynski, J. M. 1980. Characteristics of myeloperoxidase from neutrophils and other peroxidases from different cell types. In The Reticuloendothelial System. A Comprehensive Treatise. Vol. 2. Biochemistry and Metabolism. A. J. Sbarra, and R. R. Strauss, editors. Plenum Publishing Corp., New York. 255-278.

68. Albrich, J. M., C. A. McCarthy, and J. K. Hurst. 1981. Biological reactivity of hypochlorous acid: implications for microbicidal mechanisms of leukocyte myeloperoxidase. Proc. Natl. Acad. Sci. USA. 78:210-214. 